\title{
A trimetazidin hatásosságának összehasonlítása a revaszkularizált és a nem revaszkularizált stabil anginás betegeken a ONECAPS-vizsgálat alapján
}

\author{
Tomcsányi János dr. \\ Betegápoló Irgalmasrend Budai Irgalmasrendi Kórháza, Kardiológia, Budapest
}

\begin{abstract}
Bevezetés: A közelmúltban publikált ATPCI-vizsgálat azt eredményezte, hogy közvetlenül a sikeres revaszkularizáció után alkalmazott trimetazidin biztonságos volt, de nem volt effektívebb a cardiovascularis halál, anginarekurrencia, cardialis hospitalizáció tekintetében, mint a random kettős vakmódszerrel alkalmazott placebo.

Célkitüzeés: Az általunk korábban végzett ONECAPS nyitott, obszervációs vizsgálat retrospektív analízisét kívántuk elvégezni annak eldöntésére, hogy az anginás betegeknél van-e különbség a trimetazidin prolong hatásosságában annak megfelelően, hogy korábban revaszkularizáció történt.

Módszer: 1670, anginás betegből 1008 nem volt revaszkularizálva, míg 662 korábban revaszkularizáción esett át. Az életkorban, társbetegségben nem volt különbség a két csoport között. A betegeknél a heti anginaszámnak és a nitroglicerin-fogyasztásnak, illetve az angina súlyosságának a változását vizsgáltuk a trimetazidin prolong $80 \mathrm{mg}$ napi egyszeri alkalmazása során a revaszkularizált és a nem revaszkularizált betegcsoportban.

Eredmények: Mind a revaszkularizált, mind a nem revaszkularizált betegcsoportban szignifikáns csökkenést $(\mathrm{p}<0,0001)$ eredményezett a trimetazidin mind a heti anginaszámban, mind a rövid hatású nitroglicerin fogyasztásában. Emellett mindkét betegcsoportban növekedett a Kanadai Cardiovascularis Társaság (CCS) osztályozása szerinti I. súlyosságú angina aránya, és csökkent a CCS III., illetve CCS IV . aránya is. Mindezt a hatást úgy érték el, hogy a revaszkularizált betegeknél 90\% felett volt a sztatin, az ACEI/ARB, illetve a béta-blokkoló használata.

Köpetkeztetés: A trimetazidin prolong napi egyszeri $80 \mathrm{mg}$ adása szignifikánsan csökkenti a heti anginaszámot, nitroglicerin-fogyasztást, illetve az angina súlyosságát. Ezen hatása független attól, hogy a beteg korábban részesült-e revaszkularizációban vagy sem.
\end{abstract}

Orv Hetil. 2021; 162(29): 1167-1171.

Kulcsszavak: angina, trimetazidin, revaszkularizáció

\section{Comparison of the efficacy of trimetazidine in revascularized and non- revascularized stable angina patients based on the ONECAPS study}

Introduction: The recently published ATPCI study resulted in the safety of trimetazidine administered immediately after successful revascularization but was not more effective (cardiovascularis death, recurrence of angina, hospitalization for cardiac event) than the randomized double-blind placebo.

Objective: A retrospective analysis of our previously published ONECAPS open-label observational study was performed to determine whether there was a difference in the efficacy of trimetazidin prolong in the angina patients according to whether or not they had previously undergone revascularization.

Method: Of the 1670 angina patients, 1008 were not revascularized, while 662 had previously undergone revascularization. There was no difference in age or comorbidity between the two groups. Patients were examined for changes in weekly angina, short-acting nitroglycerin use and angina severity during once-daily administration of trimetazidine prolong $80 \mathrm{mg}$ in revascularized and non-revascularized study groups.

Results: In both the revascularized and non-revascularized group, trimetazidine resulted in a significant reduction $(\mathrm{p}<0.0001)$ in both weekly angina count and short-acting nitroglycerin use. In addition, the proportion of angina with Canadian Cardiovascular Society (CCS) I increased and the proportion of CCS III and CCS IV decreased in both patient groups as well. All of this effect was achieved with statin, ACEI/ARB, and beta-blocker use above $90 \%$ in revascularized patients. 
Conclusion: Trimetazidine prolong $80 \mathrm{mg}$ once daily significantly reduced the number of angina per week, the use of short-acting nitroglycerin per week, and the severity of angina. This effect is independent of whether the patient has previously received revascularization.

Keywords: angina, trimetazidine, revascularization

Tomcsányi J. [Comparison of the efficacy of trimetazidine in revascularized and non-revascularized stable angina patients based on the ONECAPS study]. Orv Hetil. 2021; 162(29): 1167-1171.

(Beérkezett: 2020. december 17.; elfogadva: 2021. január 16.)

\section{Rövidítések}

ACEI $=($ angiotensin-converting-enzyme inhibitor $)$ az angiotenzinkonvertáló enzim gátlója; $\mathrm{ARB}=$ angiotenzin-II-receptor-blokkoló; ATPCI = (efficacy and safety of trimetazidine after percutaneous coronary intervention) a trimetazidin hatásossága és biztonságossága percutan coronariaintervenció után; $\mathrm{MR}=($ modified release $)$ módosított felszívódású

Nemrégiben, az Európai Kardiológiai Társaság 2020. évi kongresszusán hirdették ki a régóta nagy érdeklődéssel várt ATPCI-vizsgálat eredményét. 2014 és 2016 között, a vizsgálat beválasztási időszakában olyan, sikeres coronariaintervención átesett betegeket randomizáltak, akiknek korábban stabil koszorúér-betegségük vagy nem ST-elevációs akut coronaria szindrómájuk volt $[1,2]$. A 6007, randomizált betegnél a napi kétszer alkalmazott trimetazidin hosszú távon is biztonságos volt, nem eredményezett azonban szignifikáns javulást a primer végpontként meghatározott cardialis halál, cardialis eredetú hospitalizáció, rekurrens angina vagy az antianginás terápia intenzitásának növelése tekintetében. A vizsgálatot számos kritika érte [3,4], de ezek közül is az egyik legfontosabb, hogy a trimetazidinterápia bevezetésének nem volt feltétele az aktuális angina vagy a dokumentált ischaemia. A vizsgálatba bevont betegek közvetlenül a sikeres katéteres intervenció után kerültek a vizsgálatba.

Éppen ezen kritikai megfontolások miatt végeztünk retrospektív analízist a ONECAPS-vizsgálat betegpopulációján [5], arra keresve a választ, hogy a korábban revaszkularizáción átesett anginás betegekben ugyanolyan hatékony-e a trimetazidin, mint a revaszkularizáció nélküli betegek csoportjában, kizárólag az angina szempontjából.

\section{Betegek és módszer}

A ONECAPS-vizsgálat egy stabil angina pectorisban szenvedő betegek bevonásával végzett obszervációs, nyílt, prospektív vizsgálat volt [5]. A vizsgálatban 1701 beteg vett rész, a revaszkularizáció szempontjából értékelhető információt azonban 1670 betegról tudtunk. A revaszkularizáció minden esetben legalább 6 hónappal a beválasztás előtt történt. Mivel ez a paraméter nem volt az eredeti vizsgálatban vizsgálati szempont, a revaszkula- rizáció óta eltelt átlagos időtartam nem ismert. A betegek revaszkularizációja vagy coronariaáthidaló mútétet jelentett (156 eset), vagy percutan coronariaangioplasticát (506 eset). Retrospektív analízisünkben az additív terápiaként napi egyszer $80 \mathrm{mg}$ dózisban alkalmazott trimetazidin prolong hatását vizsgáltuk a korábban revaszkularizáción átesett és a nem revaszkularizált betegeknél külön-külön. Analízisünk az átlagos heti anginaszám változását, a rövid hatású nitroglicerin használatát, valamint az angina súlyosságának változását értékelte a betegek e két alcsoportjában.

A vizsgált betegpopulációban a nem revaszkularizált és a revaszkularizált betegek demográfiai adatait az 1 . táblázat mutatja. A táblázat adatai alátámasztják, hogy kellően nagy számú volt mindkét betegcsoport annak vizsgálatára, hogy a napi egyszer alkalmazott trimetazidin prolong $80 \mathrm{mg}$ hatásosságát vizsgáljuk.

\section{Eredmények}

A vizsgálat revaszkularizált és nem revaszkularizált anginás betegeinek gyógyszerelésében annyi különbség adódott, hogy a revaszkularizált betegek nagyobb számban

1. táblázat |A vizsgált betegpopuláció egyes alcsoportjainak demográfiai adatai

\begin{tabular}{lcc}
\hline & $\begin{array}{c}\text { Revaszkularizált } \\
(\mathrm{n}=662)\end{array}$ & $\begin{array}{c}\text { Nem } \\
\text { revaszkularizált } \\
(\mathrm{n}=1008)\end{array}$ \\
\hline Életkor (év) & 68 & 68 \\
Férfi (\%) & 59 & 43 \\
Az angina pectoris kezdete (év) & 7,2 & 7,0 \\
Hypertonia (\%) & 93,7 & 93,4 \\
Hyperlipidaemia (\%) & 90.2 & 73.5 \\
Dohányzás (\%) & 63,4 & 51,2 \\
Korábbi infarktus (\%) & 58 & 7 \\
Diabetes mellitus (\%) & 41,8 & 34,2 \\
Pitvarfibrilláció (\%) & 16 & 14 \\
Stroke/TIA (\%) & 14 & 15 \\
Perifériás érbetegség (\%) & 22 & 14 \\
\hline
\end{tabular}

TIA = átmeneti agyi keringészavar 
Nem revaszkularizált betegek
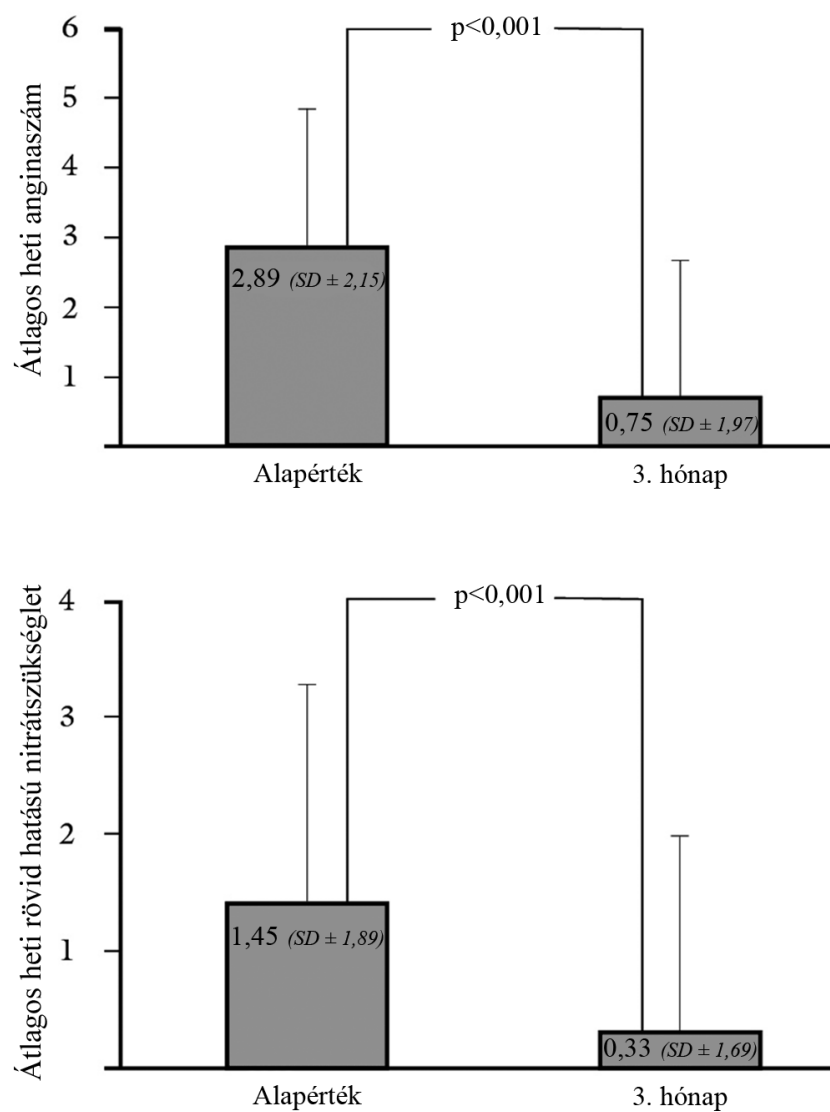

1. ábra

$\mathrm{Az}$ átlagos heti anginaszám és a rövid hatású nitrátszükséglet változása a nem revaszkularizált betegek csoportjában

részesültek kettős thrombocytaaggregáció-gátlásban, sztatinterápiában és tartós hatású nitrátterápiában is magasabb arányban részesültek, míg a revaszkularizált betegek magasabb arányban kaptak ivabradint (2. táblázat).

A három hónapon át, napi egyszeri dózisban alkalmazott trimetazadin $80 \mathrm{mg}$ kiegészítő terápia mind a heti

2. táblázat |A coronariabetegség szempontjából fontosabb gyógyszercsoportok alkalmazása az egyes alcsoportokban

\begin{tabular}{lcc}
\hline & $\begin{array}{c}\text { Revaszkularizált } \\
(\mathrm{n}=662)\end{array}$ & $\begin{array}{c}\text { Nem revaszkularizált } \\
(\mathrm{n}=1008)\end{array}$ \\
\hline TAGG & $78 \%$ & $92 \%$ \\
ACEI/ARB & $88 \%$ & $92 \%$ \\
Sztatin & $69 \%$ & $90 \%$ \\
Béta-blokkoló & $85 \%$ & $92 \%$ \\
Ivabradin & $25 \%$ & $11 \%$ \\
Ca-antagonista & $51 \%$ & $47 \%$ \\
Tartós nitrát & $24 \%$ & $35 \%$ \\
\hline
\end{tabular}

ACEI = az angiotenzinkonvertáló enzim gátlója; $\mathrm{ARB}=$ angiotenzinII-receptor-blokkoló; TAGG = thrombocytaaggregáció-gátló
Revaszkularizált betegek
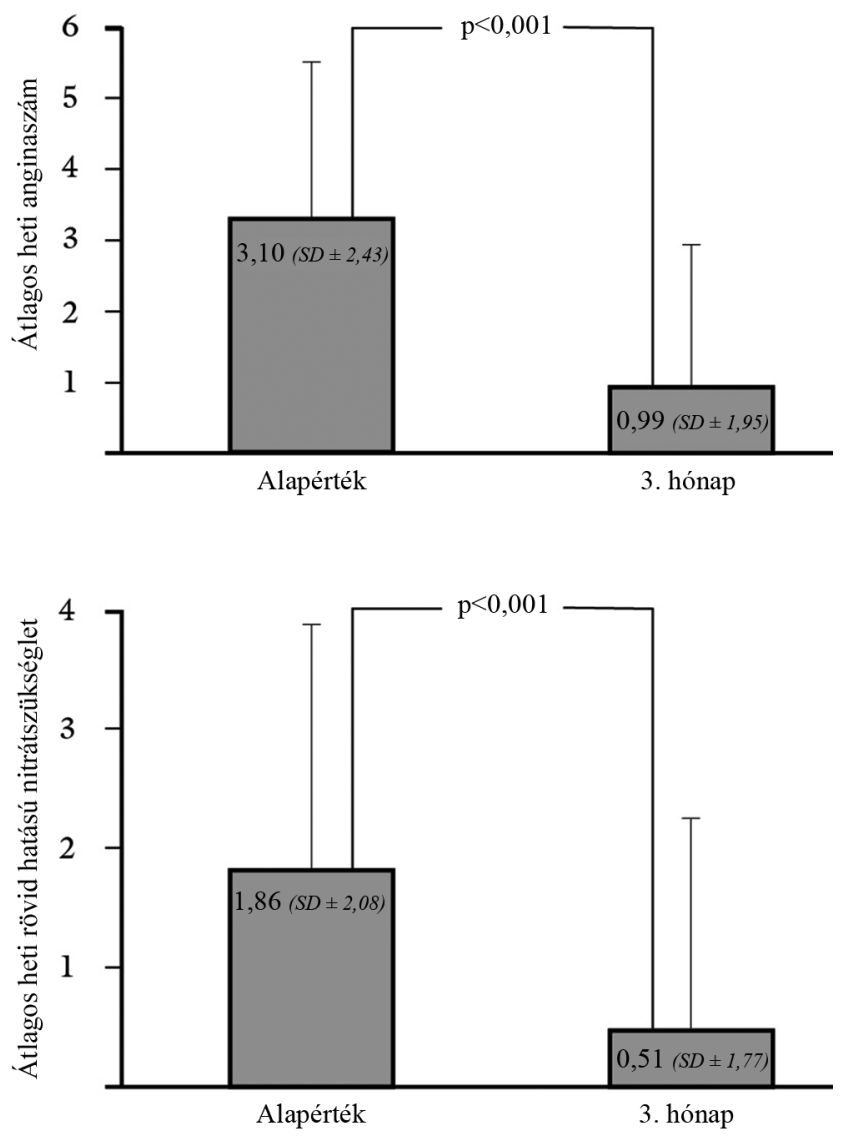

2. ábra $\quad$ Az átlagos heti anginaszám és a rövid hatású nitrátszükséglet változása a revaszkularizált betegek csoportjában

anginaszám, mind a heti, rövid hatású nitroglicerinszükséglet tekintetében szignifikáns csökkenést eredményezett a nem revaszkularizált és a revaszkularizált betegpopulációban egyaránt (1. és 2. ábra). Hasonlóan alakult az anginák súlyosságában történt változás mindkét betegcsoportban (3. ábra). Az ábra jól szemlélteti, hogy a trimetazidin prolong hatására mindkét betegcsoportban fokozatosan nőtt az enyhe anginák aránya, és csökkent a súlyosabb angina.

\section{Megbeszélés}

Vizsgálatunk eredményei alapján a napi egyszeri $80 \mathrm{mg}$ dózisban alkalmazott trimetazidin az anginás tünetekkel rendelkező betegekben - az előzményként előforduló revaszkularizációtól függetlenül - szignifikánsan csökkentette az anginaszámot, valamint az angina súlyosságát.

Összehasonlítva a közelmúltban publikált ATPCIvizsgálat eredményeivel [2], elmondható, hogy a ONECAPS-vizsgálatba bevont és revaszkularizált betegcsoport „ajánlás szerinti” gyógyszeres kezelése nem tért 


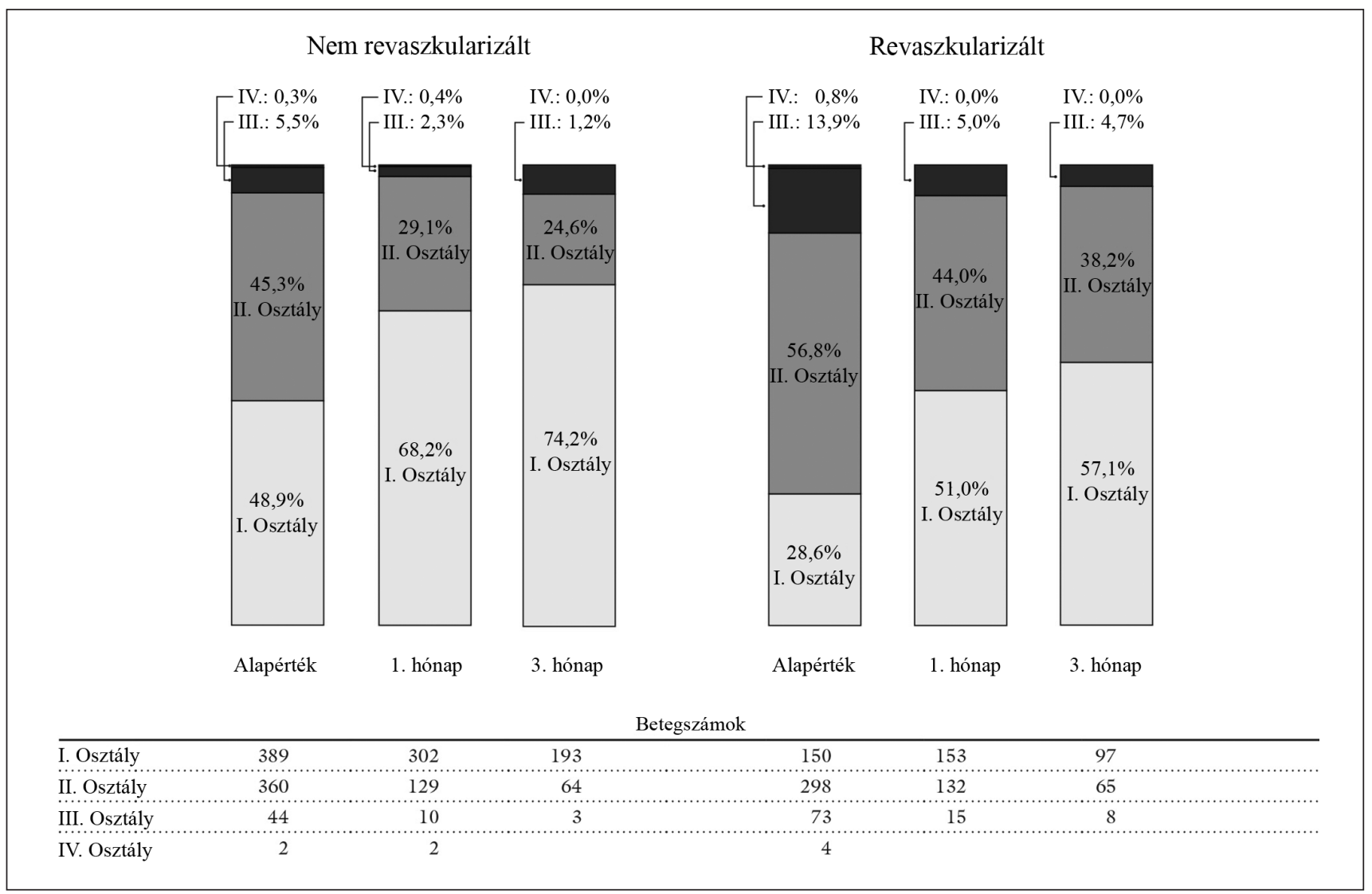

3. ábra Az angina Canadian Cardiovascular Society (CCS-) osztályok szerinti súlyosságának változása a nem revaszkularizált, illetve a revaszkularizált betegek
csoportjában

el lényegesen, azaz a betegek igen magas arányban részesültek sztatin-, ACEI- vagy ARB-terápiában és bétablokkoló kezelésben. Ezért ebből a szempontból összehasonlítható a két vizsgálat, és levonható az a következtetés, hogy a ONECAPS-vizsgálat azért volt sikeres az effektívitás szempontjából, mert a trimetazidinterápia megkezdésének feltétele az angina megléte volt. Ez a szempont sokkal fontosabbnak tûnik, mint az, hogy a ONECAPS-vizsgálat betegei egy korszerúbb, napi egyszeri adagolású trimetazidin prolong $80 \mathrm{mg}$ terápiában részesültek, míg az ATPCI-ba bevont betegek napi kétszer $35 \mathrm{mg}$ trimetazidin MR-készítményt kaptak. Nagyon nehéz egy készítménynél cardiovascularis mortalitásra vonatkozó effektivitást kimutatni akkor, ha a vizsgált betegcsoport alacsony rizikójú. Márpedig az ATPCI-vizsgálatban ez történt a trimetazidinnel. A placebocsoport éves cardiovascularis mortalitása $0,6 \%$ /év volt. Ez érthető is, ha a TIGRIS-regisztert vagy a COURAGE-vizsgálatot alapul véve $[6,7]$ a bevont betegek rizikóstatusát nézzük. Az ATPCI-vizsgálat eredményei nem a trimetazidin hatástalanságát igazolják, hanem a hatékonyság kimutatásához rosszul megválasztott betegcsoportot példázzák.

Végezetül meg kell említeni, hogy a trimetazidin prolong effektivitása mind az anginaszám-csökkenésben, mind az anginaintenzitásban megnyilvánult, de e két vizsgált paraméter változásának mértéke nem volt azonos. Ennek okát nem tudjuk. Irodalmi adatokból az ismert, hogy az angina súlyossága prediktív mind az összmortalitásra, mind a revaszkularizációra $[8,9]$.

\section{Következtetés}

1) A trimetazidin kiváló, metabolikusan ható, antiischaemiás készítmény, amely minden formában és életkorban képes az anginás panaszok számának és súlyosságának csökkentésére $[10,11]$.

2) A trimetazidin a revaszkularizációt követően is effektív az anginarekurrencia vonatkozásában, amennyiben a betegnek anginás panaszai vannak, amint azt a korábbi prospektív [12] és a jelen retrospektív vizsgálat is igazolta.

\section{A vizsgálat korlátai}

A jelen vizsgálatnak van néhány korlátja, amelyek közül a legfontosabbak a következők:

- A vizsgálat retrospektív és obszervációs volta sohasem tekinthető olyan súlyúnak, mint a randomizált prospektív vizsgálat.

- Nem tudtunk pontos időt megadni a revaszkularizáció és a vizsgálatba való bevonás között. 
- Nem vizsgáltuk a trimetazidin prolong hatásosságát a cardiovascularis halálra és a cardialis hospitalizációra, hanem csak az anginarekurrenciára.

- Nem tudtuk pontosan megmondani, hogy hány esetben volt egyér-betegség, és milyen volt a betegek balkamra-funkciója.

\section{Köszönetnyilvánítás}

Köszönöm a WEB2 Research Kft. munkatársainak, Jánosi Istvánnak és Szakács Lászlónak a statisztikai munkák elvégzését.

Anyagi támogatás: A cikk megírása anyagi támogatásban nem részesült.

A szerző a cikk végleges változatát elolvasta és jóváhagyta.

Érdekeltségek: A szerzőnek nincsenek érdekeltségei.

\section{Irodalom}

[1] Ferrari R, Ford J, Fox K, et al. A randomized, double-blind, placebo-controlled trial to assess the efficAcy and safety of Trimetazidine in patients with angina pectoris having been treated by Percutaneous Coronary Intervention (ATPCI study): rationale, design, and baseline characteristics. Am Heart J. 2019; 210: 98-107.

[2] Ferrari R, Ford I, Fox K, et al. Efficacy and safety of trimetazidine after percutaneous coronary intervention (ATPCI): a randomized, double-blind, placebo-controlled trial. Lancet 2020; 396: 830-838.

[3] Tomcsányi J, Jánosi A, Bózsik B. ATPCI: mission impossible. Ther Adv Cardiol. 2020; 3: 16-17.

[4] Patrono C, Galiuto L. Weak hypothesis? Wrong pharmacological tool? Inadequate experimental design? Comment on the ATPCI trial. Eur Heart J. 2020; 41: 4166-4167.
[5] Tomcsányi J, Szakács L. Effectiveness of trimetazidine prolong in stable coronary artery disease. Multicenter, prospective, observational study, ONECAPS study. [Stabil coronariabetegség kezelésére alkalmazott trimetazidin prolong hatásosságának vizsgálata. Multicentrikus, prospektív, obszervációs, nyílt klinikai vizsgálat, ONECAPS-vizsgálat.] Orv Hetil. 2018; 159: 1549-1555. [Hungarian]

[6] Brieger D, Pocock SJ, Blankenberg S, et al. Two-year outcomes among stable high-risk patients following acute MI. Insights from a global registry in 25 countries. Int J Cardiol. 2020; 311 : 7-14.

[7] Boden WE, Hartigan PM, Mancini J, et al. Risk prediction tool for assessing the probability of death or myocardial infarction in patients with stable coronary artery disease. Am J Cardiol. 2020; 130: 1-6.

[8] Mozaffarian D, Bryson CL, Spertus JA, et al. Anginal symptoms consistently predict total mortality among outpatients with coronary artery disease. Am Heart J. 2003; 146: 1015-1022.

[9] Owlia M, Dodson JA, King JB, et al. Angina severity, mortality and healthcare utilization among veterans with stable angina. J Am Heart Assoc. 2019; 8: e012811.

[10] Tomcsányi J, Jánosi I, Szakács L. Effectiveness of prolonged-release trimetazidine of the ONECAPS study population stratified by age. A multicenter, prospective, observational study. [Trimetazidin prolong hatásossága különböző életkorokban a ONECAPS-vizsgálat alapján.] Cardiol Hung. 2020; 50: 206-208. [Hungarian]

[11] Nagy VL, Herold Z. Clinical effect of various trimetazidine formulations in chronic coronary syndrome. [A különféle trimetazidinkészítmények klinikai hatása stabil anginával járó krónikus koszorúér-szindrómában.] Orv Hetil. 2020; 161: 611-622. [Hungarian]

[12] Xu X, Zhang W, Zhou Y, et al. Effect of trimetazidine on recurrent angina pectoris and left ventricular structure in elderly multivessel coronary heart disease patients with diabetes mellitus after drug-eluting stent implantation: a single-center, prospective, randomized, double-blind study at 2-year follow up. Clin Drug Investig. 2014; 34: 251-258.

(Tomcsányi János dr., Budapest, Árpád fejedelem útja 7., 1025 e-mail: tomcsanyij@gmail.com)

\title{
XX. ROMHÁNYI ORVOSTALÁLKOZÓ Lelkigyakorlat (manréza) orvosoknak
}

\author{
Helye: Szár, Római katolikus templom
}

Ideje: 2021. szeptember 4.

Részvételi szándékát szíveskedjék augusztus 20-ig jelezni Koltayné Bartha Magda 06-20/960 5854 telefonszámán naponta 14-16 óra között vagy a baratikor.saar@gmail.com email címen. A rendezvények eddig döntöen a résztvevők áldozatos adományaiból valósultak meg. Kérjük, hogy amennyiben lehetősége van rá, ebben az évben is támogassa rendezvényünket a Szár Községért Baráti Kör (UniCredit Bank 10918001-0000003660180000 ) részére átutalt vagy a helyszínen kapható csekken befizetett összeggel, Romhányi Orvostalálkozó megjegyzéssel. 